\title{
Strategic Aspects of Delegation
}

September 19, 1994

\author{
Bernard Caillaud* and Patrick Rey ${ }^{* *}$ \\ $\mathrm{N}^{\circ} 9422$
}

* CERAS-ENPC (CNRS) and CEPREMAP, Paris

** CREST (CNRS) Paris, and CEPR, London 


\title{
ASPECTS STRATEGIQUES DE LA DELEGATION
}

\author{
Bernard Caillaud et Patrick Rey
}

\section{Résumé}

Cet article propose un survol de la littérature sur l'utilisation stratégique de la délégation, dans des situations où une entreprise délègue certaines de ses décisions à une autre entreprise, à une filiale, une de ses directions internes etc. Déléguer peut procurer plusieurs types d'avantages : dans une perspective de court terme, cela peut améliorer la position de l'entreprise vis-à-vis de ses concurrents, ou induire une attitude moins agressive de la part de ses concurrents ; dans une perspective de plus long terme, la délégation peut rendre plus difficile l'entrée de nouveaux concurrents, ou forcer certains concurrents existants à quitter le marché. L'article analyse ces différents aspects, en insistant sur les points-clés d'engagement et de crédibilité.

Mots clés : intégration verticale, délégation, stratégies de marché, effets d'engagement. Classification CEPREMAP : I.

\section{STRATEGIC ASPECTS OF DELEGATION}

Bernard Caillaud and Patrick Rey

\begin{abstract}
$\underline{\text { Abstract }}$
This paper offers an overview of the strategic aspects of situations where, either institutionally or contractually, a firm delegates some of its decisions to another firm, a subsidiary, an internal division, etc. Delegation may have several kinds of strategic benefits: in the short-term, it may improve the competitive position of the firm, or induce a more lenient behavior from its competitors; in the long-run, it may be used to deter the entry of potential competitors, to foreclose market access or to induce actual competitors to exit. The paper analyzes the trade-off between these possible benefits and the agency costs of delegation, and emphasizes the key issues of credibility and commitment.
\end{abstract}

Key words : Vertical integration, delegation, foreclosure, precommitment effects.

J.E.L. classification number : C72, D43, D82. 
We briefly review here the literature on the "external" strategic use of vertical arrangements, where a vertical structure attempts to affect the competition with rivals. The next two papers focus instead on the "internal" impact of delegation.

The generic framework used here consists of two competing upstream manufacturers $U_{1}$ and $U_{2}$ producing substitutable goods, and two distributors $D_{1}$ and $D_{2}$, facing a final demand in the downstream market. (All firms are assumed to have constant returns to scale; "downstream" firms can alternatively be interpreted as buyers of an "intermediate good", which they transform into a final good through a fixed-coefficient technology.) The competitive game is modelled as follows. First, producers and distributors choose their contractual arrangements: integration through a vertical merger ${ }^{1}$ or separation through a particular form of delegation contract. Second, market decisions are taken.

A vertical structure, say $U_{1}-D_{1}$, can then have two kinds of "external" strategic motivations. First, it can try to directly affect the behavior of the competing structure $U_{2}-D_{2}$; attention has there focused on market foreclosure and/or entry deterrence, through "raising rivals' costs" strategies as in Salop and Scheffman [1987]. Second, it can try to "precommit itself" to a certain behavior - either a more friendly one, to induce a friendly response from its rivals, or a more aggressive one, to take advantage over rivals. We review these two motivations in turn.

\section{1 "Raising rivals' costs"}

Raising rivals' costs strategies can be used to either foreclose the market or to deter entry, at the upstream or downstream level. We first review the literature on vertical integration and focus on downstream foreclosure. We then briefly mention the literature on exclusive agreements, which has rather focused on upstream foreclosure, as well as on entry deterrence.

\subsection{Vertical Integration}

\subsubsection{The earlier literature}

The foreclosure effect of vertical integration has been a subject of controversy. The original argument relied on differences in the market shares of the merging firms, and

\footnotetext{
${ }^{1}$ Horizontal mergers (including, say, a merger between $U_{i}$ and both $D$ 's) are not considered.
} 
assumed that merging firms would stop dealing with rivals. Integrating with a large distributor, for example, would then allow a medium-size producer to expand at the expense of his rival.

Critics such as Bork [1978] or Posner [1976] argued instead that vertical integration could not increase the profitability of merging firms. They contended that a given vertical stream of production gives rise to a given amount of profits. These profits could be earned by a monopolist at any single stage of production or distribution, but could not be increased by extending a monopoly position from one stage to another.

An early response to this criticism argued that a vertical merger between, say, $U_{1}$ and $D_{1}$ effectively reduces the number of suppliers available to the rival distributor $D_{2}$, resulting in a higher wholesale price for $D_{2}$ and eventually benefiting $U_{1}-D_{1}$ in the downstream competition. However, this argument suffers from several drawbacks: first, following the merger $U_{1}-D_{1}$ may still compete with $U_{2}$ to supply $D_{2}$; second, the merger reduces the numbers of both sellers and buyers in the upstream market, and thus the effect on the wholesale price is unclear; lastly, $U_{2}$ and $D_{2}$ may "fight back", either by integrating themselves or by developing alternative efficient arrangements to avoid double marginalization. We describe below recent responses to these criticisms.

\subsubsection{Opting out versus staying in the upstream market}

Salinger [1988] shows that in a Cournot setting $U_{1}-D_{1}$ indeed prefers not to supply $D_{2}$. If selling $Q$ to $D_{2}$ does not affect the sales of $U_{2}$ but results instead in an increase of the quantity offered by $D_{2}$ in the final market, $U_{1}-D_{1}$ is better off distributing $Q$ through $D_{1}$ : this leads to the same price in the final market but brings in the additional retail profits that would otherwise go to $D_{2}$. Similarly, $U_{1}-D_{1}$ favors internal supply over buying from $U_{2}$. Salinger also considers an arbitrary number of $U$ 's and $D$ 's, and shows that, if the final demand is linear, a merger leads to an increase in the wholesale price when less than half of the $U$ 's are integrated, and to an increase of the retail price as well - even though the merged firms, facing a lower transfer price, become more aggressive in the final market - if the number of $D$ 's also is large enough.

As pointed out by Ordover-Saloner-Salop [1990], in a Bertrand setting $U_{1}-D_{1}$ has a strong incentive to supply $D_{2}$. If it did not supply $D_{2}$ then $U_{2}$ would charge the monopoly price corresponding to the demand from $D_{2}$. But then $U_{1}-D_{1}$ would better off to supply $D_{2}$ itself, at a price slightly below $U_{2}$ 's price: this would have a negligible impact on $D_{2}$ 's behavior in the final market, and would allow $U_{1}-D_{1}$ to pocket in 
the profits that would otherwise go to $U_{2}$. Hence in equilibrium both $U_{1}-D_{1}$ and $U_{2}$ supply $D_{2}$ at marginal cost, and the merger $U_{1}-D_{1}$ has no foreclosure effect.

\subsubsection{Fighting-back strategies}

Even if $U_{1}-D_{1}$ decides not to supply $D_{2}$, in order to increase the market wholesale price, $D_{2}$ may respond by integrating $U_{2}$. Ordover, Saloner and Salop [1990] also address this issue. In their Bertrand setting (with undifferentiated suppliers, producing at the same marginal cost $c$ ), in the absence of any merger, upstream competition drives the wholesale price down to $c$. If both retailers vertically integrate, their internal transfer price is again equal to $c$; thus in the new equilibrium the retail price is the same as before, and the profits of each integrated firm equal the initial aggregate profits of its constituents. If only the merger $U_{1}-D_{1}$ occurs, and assuming that $U_{1}$ stops supplying $D_{2}$, then $U_{2}$ charges $D_{2}$ with a wholesale price higher than $c$ which increases the total profits of $U_{1}-D_{1}$. At the same time it increases $U_{2}$ 's profits but decreases $D_{2}$ 's profits, so that the total profits of $U_{2}$ and $D_{2}$ may be higher or lower. If they are lower, then $U_{2}$ and $D_{2}$ have an incentive to "fight back" and merge, which in effect brings all firms back to the initial situation; in that case $U_{1}$ and $D_{1}$ have no incentive to start a merger. If they are higher, however, this "fight-back"strategy is not profitable, in which case $U_{1}$ and $D_{1}$ can effectively merge to foreclose the market.

\subsubsection{Other vertical arrangements}

The foreclosure argument relied so far on the inefficiency of linear pricing, which causes double marginalization problems; one may thus wonder whether the argument still holds when non-integrated firms can avoid such double marginalization. Hart and Tirole [1990] address this issue and consider a situation where $U_{1}$ and $U_{2}$ compete in "contracts" (in effect, two-part tariffs are sufficient). Contrary to the Ordover-SalonerSalop analysis, if both suppliers have the same costs then $U_{1}$ and $D_{1}$ have no incentive to merge: whether $U_{1}$ still supplies $D_{2}$ or not, the merger does not affect the marginal transfer price from $U_{2}$ to $D_{2}$, which they optimally set to $c$ (the merger only affects their sharing of the profits); hence the equilibrium retail price is the same, and thus $U_{1}-D_{1}$ 's aggregate profits are also the same as before the merger.

$U_{1}$ has still an incentive to merge with $D_{1}$, however, if it has a lower production $\operatorname{cost}\left(c_{1}<c_{2}\right)$. In equilibrium, $U_{1}-D_{1}$ has an incentive to undercut $U_{2}$ and supply $D_{2}$, 
but only at a price just below $c_{2}$. Thus in effect the merger $U_{1}-D_{1}$ raises the marginal transfer price for $D_{2}$, from $c_{1}$ to $c_{2}$, and the strategic benefit (foreclosure effect) of the merger will remain. Note that integrating with $U_{2}$ is not an effective "fight-back" strategy for $D_{2}$, since this would not change its marginal wholesale price.

\subsubsection{Other foreclosure effects}

Bolton-Whinston [1991] and Hart-Tirole [1990] identify other sources of foreclosure. If for example firms must initially sink some industry-specific, non-contractible investments then the same effects that previously reduced rivals' profits would now furthermore induce these rivals to invest less (or not to invest at all).

New sources of foreclosure also appear when there are uncertainties in the needs or supplies. For example, if there is only one supplier and this supplier may not be able to serve both retailers, then a retailer may want to vertically integrate to secure the supplies he needs (since merged firms fully share profits, they are indeed likely to favor internal provision over supplying the independent retailer). This in turn may induce the merging firms to invest more and the remaining firms to invest less. ${ }^{2}$

\subsection{Vertical Arrangements}

\subsubsection{Exclusive dealing and "raising rivals' costs" strategies}

It should be clear that much of the foreclosure benefits of vertical integration can also be achieved through contractual exclusive arrangements. Such role for exclusive dealing has been explored by Comanor-Frech [1985] - focusing on upstream rather than downstream foreclosure - and then further analyzed by Mathewson-Winter [1987] and Schwarz [1987], who allow producers to compete for exclusive dealership. Although they make different assumptions regarding the timing of the decisions, they all restrict attention to linear pricing. (See also Krattenmaker-Salop [1986] for a discussion of the foreclosure effects of exclusive dealing, in connection with the U.S. case law.)

More recently, Bernheim and Whinston [1992] have analyzed exclusive dealing without restricting attention to linear pricing. Assuming that two producers compete for one retailer, they show that if producers can offer two-part tariffs then they have no incentive to engage in exclusionary practices - even if one producer is more efficient than

\footnotetext{
${ }^{2}$ Investment effects are distinct in Bolton-Whiston [1991] and Hart-Tirole [1990], due to modelling differences. See Bolton and Whinston [1993] for a thorough discussion of these two papers.
} 
the other. Exclusive agreements can however emerge - and market foreclosure thus occur - when the producer-retailer relationship entails agency problems which cannot be fully solved through contracting, or when entry is at stake.

\subsubsection{Entry deterrence}

Aghion and Bolton [1987] demonstrate that established buyers and sellers can use their contractual arrangements to inhibit the entry of a more efficient seller. Assume for example that initially, only $U_{1}$ and $D_{1}$ are present, and that an alternate supplier $U_{2}$ may appear, with either higher or lower costs than $U_{1}$. An exclusive arrangement between $U_{1}$ and $D_{1}$ would effectively deter the entry of $U_{2}$, but there is apparently no reason why $D_{1}$ would accept to forego the possibility of dealing with a more efficient supplier. Aghion and Bolton however show that $U_{1}$ and $D_{1}$ may actually extract some rents from $U_{2}$, by including a provision for liquidated damages, to be paid by $D_{1}$ to $U_{1}$ if it switches to $U_{2}: U_{2}$ will then have to compensate $D_{1}$ in order to enter the market, so that in effects these "switching costs" are supported by $U_{2}$; as a result, entry is sometimes deterred (if $U_{2}$ 's cost advantage is small) but benefits $U_{1}$ when it occurs. $U_{1}$ can then redistribute part of these extra profits through an adjustment in the wholesale price. More recently, Rasmusen-Ramseyer-Wiley [1991] and Comanor-Rey [1994] have analyzed similar entry deterrence mechanisms, even in the absence of "rent-extraction" from potential suppliers. Rasmusen, Ramseyer and Wiley's argument relies on retailers' miscoordination and on a minimal efficient scale of entry for potential suppliers: the incumbent supplier can sign up a "minority block" of retailers and use the rents he can then extract from the remaining retailers to bribe the first ones. Comanor and Rey's argument relies on the fact that the entry of a new distributor or supplier may not only reinforce competition in the corresponding distribution or manufacturing stage, but also in the industry as a whole, resulting in lower aggregate profits for the incumbent firms. ${ }^{3}$

\footnotetext{
${ }^{3}$ Other vertical restraints can serve for entry deterrence purposes. In a previous version of ReyStiglitz [1993], it is shown that exclusive territories can be used to deter geographically limited entry. The idea is that with exclusive territories, independent retailers will react more fiercely than the manufacturer would do, following entry in their territories, because they would not take into account the negative impact on the manufacturer's sales on other territories.
} 


\section{Precommitment effects}

We now turn to precommitment effects and abstract from foreclosure issues by assuming that $U_{i}$ can only deal with $D_{i}$ - whether they are integrated or separated. The classical literature on precommitment effects, reviewed in subsection 2.1, assumes that delegation contracts, if any, are publicly observed. This assumption however requires a strong enforcing institutional setting to avoid false disclosure and private renegotiation of public contracts. Subsection 2.2 then discusses whether delegation with unobservable contracts can still have strategic impacts and subsection 2.3 focuses on whether public contracts may still constitute a credible precommitment device when private renegotiation is possible.

\subsection{Public Contracts}

Following Vickers [1985], precommitment through public delegation contracts in the context of producer-retailer relationships has been studied by Bonnano-Vickers [1988] and Rey-Stiglitz [1988] and [1993]. Similar ideas have also been developed to analyze the strategic aspect of managerial incentive schemes, i.e. delegation contracts between the owner of a firm and its manager, as in Fershtman-Judd [1987] and Sklivas [1987].

In our basic framework under exclusivity, $U_{1}$ has the opportunity to precommit $D_{1}$ about its future market decisions by signing a delegation contract that is publicly observed and irreversible, i.e. that constitutes a public commitment. This contract allows $U_{1}$ to manipulate $D_{1}$ 's best response function in the ensuing competition game in the retail sector. As an example, consider the choice between integration or delegation through a publicly observable two-part tariff $(F, w)$. Retail decisions are chosen by retailers, taking the wholesale price $w$ as an additive component to the marginal retail costs. $U_{1}$ can then manipulate $D_{1}$ 's best response by choosing the wholesale price $w$ : choosing $w$ above (resp. below) the manufacturing unit cost $c$ triggers a more friendly (resp. more aggressive) behavior from $D_{1}$ than under full integration where implicitly $w=c$.

The nature of market interaction then determines whether public delegation contracts should be used to induce tougher or softer behavior by the retailer. Under mild assumptions, models of price competition between differentiated products involve strategic complementarities: by precommitting to a reaction curve with higher prices than in the one-shot game, a firm induces its rival to charge higher prices in equi- 
librium, which increases its profits. In the above example, manufacturers will then choose $w>c$ to induce more friendly behavior from their retailers, therefore inducing a more collusive outcome than under integration. In models of Cournot competition however, strategic considerations lead firms to precommit to high-quantity responses so as to induce smaller market shares in equilibrium for the rivals. The conclusions are then opposite to the ones obtained above: public delegation contracts with $w<c$ are optimal delegation decisions in order to induce more aggressive behavior from the retailers. Of course, in equilibrium all competitors engage in such public contracting and the equilibrium situation may be worse for the industry as a whole.

The literature offers several examples of precommitment effects through public contracts. In all these, the delegation contract involves a clause (e.g. exclusive territories as in Rey-Stiglitz [1993]) or the determination of some parameter (e.g. a cost-sharing rule of manufacturing costs as in Fershtman-Judd [1987] or Sklivas [1987]) that credibly affects the retailer's behavior and therefore the equilibrium outcome of the market game compared to the case where contract design and market decision are simultaneous. ${ }^{4}$

\subsection{Delegation through unobservable contracts}

Very often retail contracts, e.g. wholesale prices, are secret and the only observable decision thus is whether retail activities are integrated or delegated to a retailer. In the previous example, if $(w, F)$ is not observed by the rival, $U_{1}$ and $D_{1}$ will choose $w$ so as to maximize joint profits and $F$ to share these profits, given their expectations about $D_{2}$ 's market decision. Therefore $w=c$ and the final market decision will follow the same best response function than under full integration: delegating retail activities then has no precommitment effects. If, however, franchise fees are not possible, joint profit maximization $(w=c)$ is not compatible with positive profits for $U_{1}$ (which would imply $w>c$ ). In this case, if manufacturers have some bargaining power and in a Bertrand setting, even with secret wholesale prices delegation can be used to induce a more friendly behavior by the retailers.

Katz [1991] provides a general study of the situations where delegation with unobservable contracts matters. To follow his more theoretical approach, we will assume

\footnotetext{
${ }^{4}$ Allowing contracts contingent on rivals' decisions, Fershtman-Judd-Kalai [1991] obtains Folk Theorems: any possible outcome can be sustained in equilibrium. (See also the 1987 version of Katz [1991].) Kühn [1994] shows however that forbidding such contingencies much reduces the scope for coordination.
} 
from now on that retail contracts determine transfers between $U_{i}$ and $D_{i}$ as a function of $D_{i}$ 's market decision, which is verifiable.

Delegation per se cannot matter when (unobservable) contracting allows $U_{i}$ and $D_{i}$ to achieve joint profit maximization. This will be the case when $U_{i}$ and $D_{i}$ are risk neutral profit maximizers, do not face any restriction in the contract design and have symmetric information at the contracting stage: this is the case under perfect information but also when contracts are signed before the retailer learns any private information (hidden knowledge) and assuming perfect commitment by the retailer (in particular $D_{i}$ must be able to commit itself not to quit ex-post).

Delegation with unobservable contracts can matter when the class of contracts is restricted, e.g. when as above franchise fees are ruled out. ${ }^{5}$ Restrictions can also be imposed by informational problems. Following Caillaud-Rey [1994], suppose that under full integration $U_{i}$ privately learns the value of retail cost, whereas under delegation $D_{i}$ learns the parameter and is free to quit. A trade-off appears between informational rent extraction and efficient market decision so that, at the optimum, $D_{i}$ is follows a best response function with higher prices (or lower quantities) whatever his retail cost, than under full integration: $D_{i}$ thus is committed to a more friendly behavior in the market game. Hence in a Bertrand-type model producers may choose to delegate retailing activities. However, in a Cournot-type model, delegation could only provide some credible commitment to a best-response function with lower quantities, which a firm does not wish when competing in strategic substitutes. Caillaud-Hermalin [1993] build a similar model to analyze strategic effects of delegation in a signalling model of entry deterrence, where relevant information is about retail costs. Without delegation, the stable signalling equilibrium requires $U_{1}$ to choose higher quantities than under perfect public information when retail cost is low. Delegation can be part of an equilibrium because informational agency problems impose under-production for high retail cost, which relaxes the separating equilibrium condition and thus reduces the costs of signalling. ${ }^{6}$

A second route investigated by Katz [1991] amounts to assuming some kind of

\footnotetext{
${ }^{5}$ Considering also a restricted class of contracts, Fershtman-Kalai [1993] analyzes a specific discrete model where indifferences are ruled out in the retailers' preferences and where private delegation matters. They also show that, in a model close to Katz's basic setup, a small probability of public observability of contracts is sufficient to make private delegation matter.

${ }^{6}$ Martimort [1994] and Leoty [1994] develop similar ideas to analyze the choice between delegation through exclusive retailers or through common retailers with unobservable contracts.
} 
intrinsic difference ex-ante between $U_{i}$ and $D_{i}$, either because $D_{i}$ is better informed then $U_{i}$ at the contract stage, or because $U_{i}$ and $D_{i}$ have different attitudes towards risk in profits; delegation through private contracts may again matter, but for selection reasons or for insurance reasons rather than for strategic aspects per se.

\subsection{Secret renegotiation of public delegation contracts}

Dewatripont [1988] first pointed out that public disclosure of a fully binding contract does not rule out later renegotiation of a new arrangement to the mutual benefits of contracting parties. In the simple model of delegation with two-part tariffs, if a public contract $\left(w^{0}, F^{0}\right)$ can be renegotiated secretly by $U_{i}$ and $D_{i}$, both parties will renegotiate a joint-profit maximizing contract with $w=c$ and delegation will have no precommitment effects, as in the case of unobservable delegation contracts. However, there are some instances where delegation with public contracts subject to renegotiation can have precommitment effects that would not appear with unobservable contracts. This question is addressed in Dewatripont [1988] and more systematically investigated in Caillaud-Jullien-Picard [1993].

Public contracts subject to private renegotiation cannot matter if unobservable renegotiation results into the same retailer's behavior as under unobservable delegation contracts. That would be the case with unrestricted renegotiation under perfect information, but also in hidden knowledge situations with perfect commitment by the retailer.

Caillaud-Jullien-Picard [1993] analyzes a situation of hidden knowledge about retail costs, with imperfectly binding contracts for the retailers (i.e. with ex-post participation constraints). At the renegotiation stage, $U_{i}$ and $D_{i}$ are bound by the public existing delegation contract, that implicitly promises $D_{i}$ some expected rent. If this rent is low enough, the optimal renegotiated contract will look like the optimal unobservable delegation contract, with under-production compared to full information for high cost retailers and informational rents to low cost retailers - these rents are then sufficient to ensure ex-ante acceptance of the renegotiated contract by $D_{i}$. If, however, the rent promised is large enough, inducing ex-ante participation by $D_{i}$ will limit $U_{i}$ 's concern about rent extraction and will therefore reduce the need of ex-post inefficient market decision. This means that a high-rent, public delegation contract will induce a renegotiated outcome with more aggressive market decisions (higher quantities, lower 
retail prices) than would purely unobservable delegation contracts. The conclusion again depends on the nature of the market game: in Cournot models, $U_{i}$ will publicly disclose $D_{i}$ 's tough incentives, which will be robust to renegotiation, whereas in a model of Bertrand competition between differentiated products, public disclosure of delegation contracts is of no use, since it could only support a credible commitment to lower retail prices.

\section{References}

[1] Aghion, P. and P.Bolton, [1987]: "Long-Term Contracts as a Barrier to Entry", American Economic Review, Vol. , pp. .

[2] Bernheim, B.D. and M.D.Whinston, [1992]: "Exclusive Dealing", Harvard Institute of Economic Research Discussion Paper 1622, Harvard University.

[3] Bolton, P. and M.D.Whinston, [1991]: "The 'Foreclosure' Effects of Vertical Mergers", Journal of Institutional and Theoretical Economics, Vol. 147, pp.207-226.

[4] Bolton, P. and M.D.Whinston, [1993]: "Incomplete Contracts, Vertical Integration and Supply Assurance", Review of Economic Studies, Vol. 60(1), pp.121-148.

[5] Bork, R.H., [1978], The Antitrust Paradox, New-York: Basic Books.

[6] Bonnano, G. and J.Vickers, [1988]: "Vertical Separation", Journal of Industrial Economics, Vol 36, pp 257-65.

[7] Brander, J.A. and B.J.Spencer, [1985]: "Export Subsidies and International Market Share Rivalry", Journal of International Economics, Vol 18, pp 83-100.

[8] Caillaud, B., B.Jullien and P.Picard, [1993]: "Competing Vertical Structures: Precommitment and Renegotiation", mimeo CEPREMAP, forthcoming Econometrica.

[9] Caillaud, B. and B.Hermalin, [1993]: "The Use of an Agent in a Signalling Model", Journal of Economic Theory, Vol 60-1, pp 83-113.

[10] Caillaud, B. and P.Rey, [1994]: "Strategic Ignorance in Producer-Distributor Relationships", in progress. 
[11] Comanor, W.S. and H.E.Frech III, [1985]: "The Competitive Effects of Vertical Agreements?", American Economic Review, Vol. 75(3), pp. 539-546.

[12] Comanor, W.S. and P.Rey, [1994]: "Vertical Restraints and the Market Power of Large Distributors", mimeo.

[13] Dewatripont, M., [1988]: "Commitment through Renegotiation-Proof Contracts with Third Parties", Review of Economic Studies, Vol LV, pp 377-90.

[14] Fershtman, C. and K.L.Judd, [1987]: "Equilibrium Incentives in Oligopoly", American Economic Review, Vol 77, pp 927-40.

[15] Fershtman, C. and E.Kalai, [1993]: "Unobserved Delegation", MEDS DP 1043, Northwestern University.

[16] Fershtman, C., K.L.Judd and E.Kalai, [1991]: "Cooperation through Delegation", International Economic Review, Vol 32, pp 551-559.

[17] Hart, O. and J.Tirole, [1990]: "Vertical Integration and Market Foreclosure", Brookings Papers on Economic Avtivity: Microeconomics, 205-276.

[18] Katz, M., [1991]: "Game-Playing Agents: Unobservable contracts as Precomitments", The RAND Journal of Economics, Vol 22-3, pp 307-328.

[19] Krattenmaker, T.G. and S.C.Salop, [1986]: "Anticompetitive Exclusion: Raising Rivals' Costs to Achieve Power Over Price", Yale Law Journal, Vol. 96, pp. 209-93.

[20] Kühn, K.U., [1994]: "Non-linear Pricing in Vertically Related Duopolies", mimeo CSIC Barcelona.

[21] Leoty, C., [1994]: "Multiprincipaux, agence commune et utilisation stratégique des incitations compensatoires", mémoire de DEA, EHESS, Paris.

[22] Martimort, D., [1994]: "Exclusive Dealing, Common Agency and Multiprincipals Incentive Theory", mimeo IDEI.

[23] Mathewson, F. and R.A.Winter, [1987]: "The Competitive Effects of Vertical Agreements: Comment", American Economic Review, Vol 77(5), pp. 1057-1062.

[24] Ordover, J.A., G.Saloner and S.Salop, [1990]: "Equilibrium Market Foreclosure", American Economic Review, Vol 80, pp.127-142. 
[25] Posner, R.A., [1976], Antitrust Law, Chicago: University of Chicago Press.

[26] Rasmusen, E.B., J.M.Ramseyer, and J.S.Wiley, [1991]: "Naked Exclusion", American Economic Review, Vol. 81(5), pp. 1137-1145.

[27] Rey, P. and J.Stiglitz, [1988]: "Vertical Restraints and Producers'Competition", European Economic Review, Vol 32, pp 561-568.

[28] Rey, P. and J.Stiglitz, [1993]: "The Role of Exclusive Territories in Producers'Competition", mimeo INSEE.

[29] Salinger, M.A. [1988]: "Vertical Mergers and Market Foreclosure", Quarterly Journal of Economics, Vol 77, pp. 345-356.

[30] Salop, S.C. and D.T.Scheffman, [1987]: "Cost-Raising Strategies", Journal of Industrial Economics, Vol. 36, pp. 19-34.

[31] Schwartz, M., [1987]: "The Competitive Effects of Vertical Agreements: Comment", American Economic Review, Vol 77(5), pp. 1063-1068.

[32] Sklivas, S.D., [1987]: "The Strategic Choice of Managerial Incentives", The RAND Journal of Economics, Vol 18, pp 452-458.

[33] Vickers, J., [1985]: "Delegation and the Theory of the Firm", The Economic Journal, Economic International Conference Supplement, Vol 95, pp 138-147. 